\title{
Fonološki opis govora Dovjega
}

\author{
JoŽICA ŠKOFIC \\ Inštitut za slovenski jezik Frana Ramovša, ZRC SAZU, Novi trg 2, \\ SI-1000Ljubljana,guzej@zrc-sazu.si
}

SCN VI/1 [2013], 18-37

V prispevku je predstavljen krajevni govor Dovjega na Gorenjskem, ki je tudi točka Slovenskega lingvističnega atlasa (SLA T195). Fonološki opis, ki zajema inventar, distribucijo in izvor fonemov in prozodemov, je nastal večinoma na osnovi zapisa dovškega krajevnega govora po vprašalnici za Slovenski lingvistični atlas iz leta 1967, dopolnjen pa je z zapisi narečnih besedil, posnetih pozimi 2013, in predvsem na glasoslovni ravnini primerjan z govorom Plavškega Rovta in nekaterih drugih vasi na tem območju.

The article presents the phonological description of the local dialect of Dovje (SLA T195) in Upper Carniola (Gorenjska). Thus it contains an inventory of phonemes and prosodemes of this dialect, describes their distribution, and the last part is about their origin. This phonological description has been prepared on the basis of dialect recordings from 1967 (the material has been collected with the questionnaire for Slovene Linguistic Atlas), complemented by recordings of dialect discourses from 2013. The local dialect of Dovje is compared with other neighbouring local dialects.

Ključne besede: fonološki opis, gorenjsko narečje, Slovenski lingvistični atlas, Dovje

Key words: phonological description, Gorenjsko/Upper Carniola dialect, Slovene Linguistic Atlas, Dovje

\section{Uvod $^{1}$}

$\gg V$ jezikovnem pogledu nenavadno zanimiva je Zgornjesavska dolina od Jesenic do Rateč. Znano je, da je bil ta predel slovenske zemlje naseljen kasneje kot Gorenjska do Jesenic. Danes pa imamo tu močno naseljena središča na Hru-

\footnotetext{
${ }^{1}$ Vnašalni sistem ZRCola je na Znanstvenoraziskovalnem centru SAZU v Ljubljani Peter Weiss razvil za jezikoslovne, predvsem dialektološke potrebe in deluje v Microsoftovem programu word v operacijskem sistemu windows. Temelji na standardu unikod.
} 
šici, Dovjem in v Mojstrani, v Gozd-Martuljku, Kranjski Gori, Podkorenu in Ratečah. Vse te vasi so področje mlajše kolonizacije, nedvomno pa je starost njihovega nastanka dokaj različna /.../« (Logar 1996: 40). »Če potujemo iz Kranjske Gore preko Gozd-Martuljka po savski dolini navzdol, opazimo, da tipični koroški narečni pojavi, to je taki, ki niso skupni koroščini in gorenjščini, vse bolj pojemajo, dokler nekako v Belci ne zamro. Dovje in Mojstrana govorita že gorenjščino, vendar pa se $\mathrm{v}$ dveh izredno značilnih pojavih ločita tako od gorenjščine kakor tudi od sosednjih zahodnogorenjskih-koroških govorov. Ta dva pojava sta dovško-mojstranska refleksa za psl. $\check{e}$ in $\check{o}$, namreč exi in o: $u$. /.../ Refleksa e:i in o:u sta razvojno na tem področju nemogoča, ker izhajata iz bistveno drugačne osnove kot gorenjska ẹ: $/ e^{r}$ ali koroška $i^{r}, u^{r}{ }^{2}$ Ta dva refleksa sta na Slovenskem znana samo po Štajerskem in v vzhodni dolenjščini. Zato dovško-mojstranska ẹ: in o: $u<$ < in $\ddot{o}$ zgovorno in nedvomno pričata o tem, da so v ta dva kraja prišli kolonisti bodisi iz osrednje Štajerske bodisi z Dolenjskega. /.../ Ker pozna vzhodna dolenjščina enake reflekse za $e \check{e}$ in $\ddot{o}$ kot ta dva gorenjska kraja /.../, se sama po sebi vsiljuje misel, da sta dovški in mojstranski ẹ:i in o:u po vsej verjetnosti dolenjska refleksa za $\check{e}$ in $\ddot{o}$, ki so jih na gorenjski teritorij zanesli brižinski kolonisti iz teh dolenjskih krajev. /.../ Mlajši rod refleksov ẹ:i in o:u ne govori več dosledno. Odločilna pri tem je šola, gorenjska okolica, izredno hiter porast zlasti Mojstrane v zadnjem desetletju « (Logar 1996: 42).

Kasnejše raziskave slovenskih narečij po gradivu za SLA (npr. Rigler 1965, Rigler 1967) kažejo, da gre najverjetneje za ostanek starejše stopnje v razvoju gorenjščine, ko še ni prišlo do monoftongizacije ei in ou. O tem je kako desetletje po prvi razpravi o zgornjesavskih govorih T. Logar zapisal: »/.../ V nekem pogledu še bolj zanimiva pa je govorica Dovjega in Mojstrane, ki je v glavnem že gorenjska, vendar pa jo dva važna osnovna vokalna refleksa, namreč ei in ou za psl. psl. $\hat{e}$ in $\bar{o}$, ločita od nje in jo družita s slovenskimi jugovzhodnimi narečji (snểix, rôux). Ta nenavadni pojav si lahko razlagamo na dva načina, ali sta ta dva refleksa sled neke zelo stare kolonizacije Dovjega s prebivalci, ki so za $\hat{e}$ in $\bar{o}$ govorili $e i$ in $o u$, pri čemer prihajajo teoretično in zgodovinsko v poštev zlasti Dolenjci, ali pa sta ostanka nekoč povsod po Gorenjskem razširjenih ei in ou za $\hat{e}$ in $\bar{o}$. Glede na vse, kar danes že vemo o postanku gorenjskega monoftongičnega sistema, se mi zdi sedaj ta domneva celo bolj verjetna, čeprav tudi prva razlaga ni nemogoča« (Logar 1962/63: 309).

Z vprašanjem vzporednega zvišanja $* \check{e}$ in $* \bar{o}$ v slovenščini se je ukvarjal tudi Greenberg $2002^{3}$ in ob ugotovitvi, da je $s$ »/.../ stališča jezikovne geografije /.../ smiselno domnevati, da se je zvišanje *̌ najprej začelo na slovenskem severozahodu, nato pa se je širilo proti jugu in vzhodu /.../« (Greenberg 2002:

2 Ta hipoteza je bila na podlagi povojnih raziskav za SLA popravljena v začetku šestdesetih let (Logar 1962/63: 3) (op. K. Kenda-Jež v Logar 1996).

${ }^{3} \mathrm{~V}$ tem poglavju se sklicuje tudi na ugotovitve W. R. Vermeerja v razpravi »Raising of * $e^{2}$ and Loss of the Nasal Feature in Slovene«, objavljeni v Zborniku za filologiju $i$ lingvistiku, 1982, 25/1, 97-120. 
135), izpostavil tudi posebnost govora Dovjega in Mojstrane: »Dva gorenjska govora, Dovje in Mojstrana (zgornjesavska dolina), izkazujeta odraze s padajočim dvoglasnikom, npr. Dovje snệix, mlẹik /.../, brẹiza /.../, bộux, nộuč /.../. Domnevo, da so dvoglasniki tu arhaični, podpira dejstvo, da v sosednjih vaseh, ki imajo monoftongične odraze, v nasprotju z običajnim gorenjskim razvojem ti odrazi niso sovpadli z $e$-jevskimi in $o$-jevskimi samoglasniki iz drugih virov /.../« (Greenberg 2002: 136). ${ }^{4}$

Krajevni govor Dovjega, ki je tudi točka Slovenskega lingvističnega atlasa (SLA T195), je bil po Vprašalnici za SLA zapisan že leta 1967, avtorica tega zapisa je takratna študentka slovenistike na Filozofski fakulteti v Ljubljani Regina Razinger (Razinger 1967). Njen zapis vsebuje tudi kratek glasoslovni in oblikoslovni opis govora (delo je nastalo pod mentorstvom prof. Tineta Logarja v okviru zbiranja narečnega gradiva za Slovenski lingvistični atlas), ${ }^{5}$ shranjen pa je v arhivu Dialektološke sekcije Inštituta za slovenski jezik Frana Ramovša ZRC SAZU v Ljubljani. Ta zapis je bil osnova za nastanek tukajšnjega fonološkega opisa v obliki, kot je uveljavljena v sodobni slovenski dialektologiji (prim. za gorenjske točke SLA Škofic 1997, 1999, 2000). Arhivsko gradivo je bilo leta 2013 dopolnjeno z novimi zapisi dovškega krajevnega govora in govorov nekaterih sosednjih vasi (tj. Plavškega Rovta, Žerjavca nad Jesenicami in Belce), ${ }^{6}$ zato je v prispevku glasoslovna podoba dovškega govora lahko primerjana $\mathrm{z}$ govori sosednjih vasi na tem območju.

Krajevne govore, ki so predmet te razprave, je natančno jezikoslovno (in predvsem imenoslovno) raziskoval ter svoja dognanja v doktorski disertaciji Imenoslovje zgornjesavskih dolin (Čop 1983) in v več člankih objavil tudi že dr. Dušan Čop - njegovo objavljeno gradivo in interpretacija le-tega sta seveda prav tako pomembno prispevala k nastanku tukajšnjega članka. Z analizo narečnega imenskega gradiva je potrjeval hipotezo, da »/.../ obravnavano področje narečno ni enotno, da je govor Mojstrane, Dovjega, Belice, Zg. Radovine, pa tudi Plavškega Rovta, Planine pod Golico in Prihodov v veliki meri vsaj v osnovah dolenjskega porekla (vendar s to razliko, da so prebivalci vasi pod Golico v celoti sprejeli gorenjsko palatalizacijo, medtem ko so naseljenci v Mojstrani in na Dovjem substituirali palatalizirani ziljsko-koroški (gorenjski) $-k$ '- pred $-e$ - in $-i$ - (torej $-c$ - oz. $-\check{c}-$ ) $\mathrm{s}-t-, / \ldots /$ ). Prebivalci vseh omenjenih naselij so $\mathrm{v}$ večjem številu naseljenci z Dolenjskega, odkoder so jih s svojih posesti Otoka in okolice kot kovaške mojstre po uničenju srednjeveškega Gutenwertha freisinški škofje z družinami preselili na območje svoje zgornjesavske posesti na Dovjem in v Mojstrani (Ivo Pirkovič). Od tam se je fužinarstvo preneslo tudi v vasi pod Golico oz. na Jesenice. Na to, da je govor Mojstrane in Dovjega v svojih osnovnih značilnostih dolenjski, je v Slavistični reviji V-VII/1954 opozoril že Tine Logar (diftongizacija - $\bar{e}-$ in $-\bar{o}-\mathrm{v}-e \underline{i}$ - in -ou-), namen te disertacije pa je to

\footnotetext{
${ }^{4}$ V nadaljevanju Greenberg izpostavlja značilnosti v osnovi ziljskega govora Podkorena.

${ }^{5} \mathrm{O}$ Slovenskem lingvističnem atlasu na: http://isjfr.zrc-sazu.si/sl/publikacije/slovenski-lingvisticni-atlas-1\#v.

${ }^{6}$ Avtorica teh zapisov na podlagi lastnih terenskih raziskav je Jožica Škofic.
} 
prikazati tudi semantično in etimološko. Priseljenci z Dolenjskega (in pozneje iz Poljanske doline) so se morali naseliti v omenjenih krajih v dobi, ko je v ziljsko-koroškem oz. gorenjskem narečju že dozorela ali vsaj dozorevala večina glasovnih sprememb (torej v 14. in 15. stoletju). Gorenjske oz. ziljsko-koroške glasovne in druge posebnosti so priseljenci v svojem govoru deloma sprejeli (razen palatalizacije glasu $-k$-), vendar so pri tem ohranili tudi nekaj značilnosti svojega dolenjskega govora (predvsem diftongizacijo, zategnjen govor in močno poudarjeni - $r$-), in to kljub močnim vplivom gorenjskega in ziljsko-koroškega narečja« (Čop 1983: 9-10).

Današnja glasoslovna podoba dovškega govora se večinoma ujema s tisto, ki je prikazana v omenjenih delih, le dvoglasnikov ei in ou tu zaradi zbliževanja s sosednjimi gorenjskimi govori skorajda ni več slišati (o tem več v nadaljevanju).

\section{Fonološki opis govora kraja Dovje (SLA T195)}

V nadaljevanju je predstavljena fonološka ravnina gorenjskega krajevnega govora kraja Dovje v Zgornjesavski dolini. V prvem delu je predstavljen inventar fonemov (samoglasnikov in soglasnikov) in prozodemov, sledi predstavitev distribucije/razporeditve fonemov in njihovih položajnih različic/alofonov ter prozodemov, v tretjem delu pa je prikazan njihov izvor iz izhodiščnega ( $\mathrm{tj}$. popraslovanskega) splošnoslovenskega fonološkega sistema (prim. Logar 1981).

\section{Inventar}

\subsection{Samoglasniki}

3.1.1 Dolgi naglašeni samoglasniki

$i$ $u:$

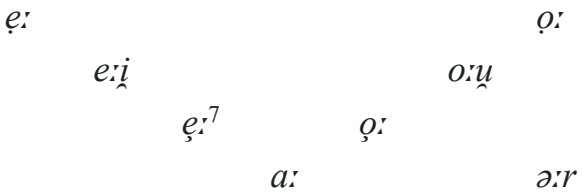

\footnotetext{
${ }^{7} \mathrm{~V}$ tem fonološkem opisu je ohranjen zapis širine dolgih $e$ in $o$ s kljukico pod samoglasnikoma (kot v rokopisu), čeprav posnetki iz leta 2013 kažejo, da gre za navadno širino, ki se v sodobni slovenski fonetični transkripciji ne uporablja več. Besedila iz leta 2013 $\mathrm{v}$ tem prispevku torej širine nimajo več posebej označene, ampak velja, da so ozki samoglasniki tu označeni s pikico pod $e$ in $o(e, o)$, šroka $e$ in $o$ pa sta brez diakritičnega znamenja.
} 
3.1.2 Kratki naglašeni samoglasniki

(i)

e

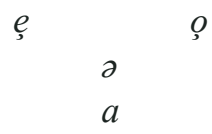

3.1.3 Kratki nenaglašeni samoglasniki

3.1.3.1 Prednaglasni samoglasniki

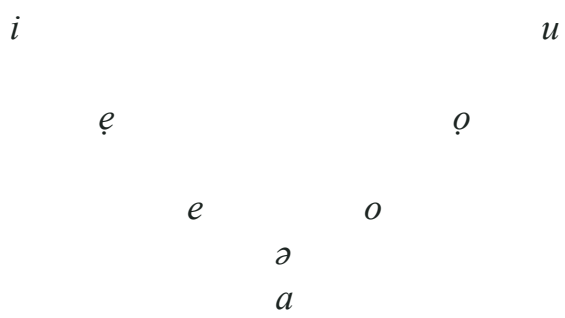

3.1.3.2 Ponaglasni samoglasniki

$\begin{array}{lll} & & \\ & & \\ & & \\ & & \\ & & \end{array}$

3.1.3.3 Izglasni samoglasniki

$\begin{array}{cccc} & & & \\ & & & \\ & & & \\ & & & \\ & & & \\ & & & \\ & & & \\ & & & \end{array}$




\subsection{Soglasniki}

\subsubsection{Zvočniki}

$\begin{array}{llll}u & & & m \\ j(i)^{8} & & & \end{array}$

\subsubsection{Nezvočniki}

$\begin{array}{llll}p & b & f & \\ t & d & & \\ c & & s & z \\ \check{c} & (\check{\zeta})^{9} & \check{s} & \check{z} \\ k & g & x & \end{array}$

\subsection{Naglas}

3.3.1 Naglas ni vezan na določeno mesto v besedah - naglasno mesto je svobodno.

3.3.2 Govor pozna kvantitetno opozicijo (dolge naglašene, kratke naglašene in kratke nenaglašene zloge).

3.3.3 Govor pozna tonemsko opozicijo na dolgih zlogih: rastoči naglas (akut $V^{\prime}:$ in padajoči naglas (cirkumfleks - V̀:).

3.3.4 Na kratkih naglašenih samoglasnikih, ki so mogoči le v zadnjih ali edinih zlogih, je naglas le jakostni ('V).

3.3.5 Inventar prozodemov torej zajema tri naglase $\left(\mathrm{V}^{\prime}: \mathrm{V}_{:},{ }^{\prime} \mathrm{V}\right)$ in nenaglašeno kračino (V).

\section{Distribucija}

\subsection{Samoglasniki}

\subsubsection{Dolgi naglašeni samoglasniki}

4.1.1.1 Dolgi naglašeni samoglasniki so mogoči v katerem koli besednem zlogu.

${ }^{8}$ Znak $i$ označuje samoglasniški izgovor $j$, kot se govori (oz. se je govoril) v dvoglasniku e:i ali namesto $j \mathrm{v}$ izglasju in $\mathrm{v}$ položaju pred soglasnikom.

${ }^{9}$ Fonem $\breve{\zeta}$ se govori le v novejših izposojenkah (npr. క̌ẹ:zva 'džezva - posoda za kuhanje kave') in kot zveneča različica fonema č pred zvenečimi nezvočniki ('̌bẹ̀sva 'čebela'). 
4.1.1.2 Samoglasnika /o: / in /o:/ večinoma nista možna v vzglasju - pred njima je protetični /u/ (uó́rrx 10 'oreh', uọ̀rrgle 'orgle', uọ̀xxcat 'ohcet', ${ }_{11}^{11}$ uó:kan 'okno'). 4.1.1.3 Samoglasnika /ẹı/, /ọ:/ se govorita v (izvorno) predzadnjih besednih zlogih (žẹ́:na, nớ:ga).

\subsubsection{Kratki naglašeni samoglasniki}

4.1.2.1 Ti so mogoči le v zadnjih ali edinih besednih zlogih.

4.1.2.2 Kratki naglašeni /i/ je redek, morda celo idiolektalen ( $\check{s}^{\prime} l i$ 'šli'), ker je večinoma oslabel v polglasnik ('nat 'nit').

4.1.2.3 V položaju pred istozložnim /j/ oz. /i/ se /a/ ne pojavlja - namesto njega govorijo /e/ ('dei 'daj' - vel., 2. os. ed.).

\subsubsection{Kratki nenaglašeni samoglasniki}

4.1.3.1 Govor ima v prednaglasnem položaju osem samoglasnikov, v ponaglasnem položaju pet, $\mathrm{v}$ izglasnem položaju pa šest.

4.1.3.2 V položaju pred istozložnim /j/ oz. /i/ se /a/ ne pojavlja - namesto njega govorijo lel (dérinueite 'delajte').

\subsection{Soglasniki}

\subsubsection{Zvočniki}

4.2.1.1 Zvočnik $/ n /$ ima pred mehkonebniki različico [n] ( $a \eta^{\prime} g a$ 'enega').

4.2.1.2 Zvočnik /j/ ima pred soglasniki in v izglasju različico [i] (dériuei 'delaj', dé:iueite 'delajte').

4.2.1.3 Zvočnik /l/ se ne govori pred zadnjimi samoglasniki - za govor je značilno švapanje (uídua 'videla', uàaš 'laž', mua'təč 'mlatič'). ${ }^{12}$

${ }^{10}$ Gradivo je zapisano tako kot $\mathrm{v}$ rokopisnem gradivu iz arhiva za SLA, le zapis tonemov je posodobljen ( $V^{\prime}>V^{\prime}, \hat{V}>V_{i}, \ddot{V}>$ 'V).

${ }^{11}$ Informator iz Plavškega Rovta, Klemen Klinar (rojen 1981), pozna tudi različici vọ:fcət (z asimilacijo $x c>f c$ ) in vọ̀xtac (z metatezo $c-t>t-c$ ), verjetno iz govora Blejske Dobrave tudi vọ̀:ftac (z nadaljnjo asimilacijo $x t>f t$ ).

12 Švapanje je izrazita značilnost tudi sosednjih gorenjskih krajevnih govorov (npr. v Plavškem Rovtu: i ré:kva 'je rekla', i bva 'je bila'). 


\subsubsection{Nezvočniki}

4.2.2.1 Po zvenečnosti se nezvočniki prilagajajo sledečemu nezvočniku - asimilacija po zvenečnosti (gnérist 'gnezdo', opxají'u 'obhajilo', bá:pca 'babica, tj. kol v plotu', rẹ́:tkua 'redkev', suáritka 'sladka', ré:intka 'redka', pọ́:tkua 'podkev', ${ }^{13}$ d'ga 'tega')

4.2.2.1.1 Pred zvenečimi nezvočniki ima /č/ različico [క̌] (క̌bú:ua 'čebula').

4.2.2.2 V izglasju so možni le nezveneči nezvočniki - zveneči nezvočniki imajo tam svoje nezveneče pare ('gat 'gad', g'rop 'grob', lẹ́:meš 'lemež', zò:p 'zob', pog'rẹp 'pogreb', mò̀uš 'mož', ot kọ́t' 'od kod').

4.2.2.2.1 Soglasnik /g/ ima v izglasju nezvenečo različico [x] (drọ:x 'drog', s'to'ux 'stog', rò'ux 'rog', bò'ux 'bog').

\subsection{Naglas}

4.3.1 Dolgi naglašeni samoglasniki so možni v vseh besednih zlogih.

4.3.2 Kratki naglašeni samoglasniki so možni le v zadnjih ali edinih besednih zlogih.

4.3.3 Nenaglašenih dolgih samoglasnikov govor ne pozna.

4.3.4 Govor ima dolgi nedoločnik (smejást se 'smejati se', pokopá:te 'pokopati', stegnìt se 'stegniti se, umreti', kropìte 'kropiti', šiuá:te 'šivati', klepá:te 'klepati', tesá:te, klečá:tẹ) - toda tudi kratkega (obrá:čat(e) 'obračati'). ${ }^{14}$

\section{Izvor}

\subsection{Samoglasniki}

\subsubsection{Dolgi naglašeni samoglasniki}

i: $\quad<i:$ (zírma, suínna, lìst, zìt, píršem)

$<$ kratki akutirani $i$ v nezadnjih besednih zlogih (lí:pa, rí:ba, xírša)

$<$ v izposojenkah (sìrk 'koruza')

u: < u: (xrù:ška 'hruška', ứčc 'luč', lú:pəm, olù:pək, lú:bje)

$<$ kratki akutirani $u$ v nezadnjih besednih zlogih (kú:pa, krú:xa - R ed., mú:xa)

$<$ včasih unu' < lù' (gùrx 'gluh')

$<\mathrm{v}$ izposojenkah (fù̀tər 'krma')

ẹ: <ẹ: (pẹ̀st, pẹ́:tak 'petek', imẹ̀:, pẹ̀st, uẹ́:žem, plệršem, grẹ́:da)

$<$ kratki akutirani $e$ v nezadnjih besednih zlogih (dé:tela 'detelja')

${ }^{13}$ V Plavškem Rovtu poznajo asimilacijo $d-k>x$ - $k$ : pó: $x k u$ 'podkev'.

${ }^{14}$ V Plavškem Rovtu govorijo npr.: pozabít 'pozabiti' (inf. J. Klinar), xpí:t 'kupiti', žvẹ́:t 'živeti', itẹ́: 'iti' (inf. K. Klinar). 
< cirkumflektirani er (pẹ̀rč, uečẹ:rr, drevè̀ssa - R ed., sarcèr: 'srce')

< novoakutirani $e \mathrm{v}$ nezadnjih besednih zlogih (zẹ́:le, žẹ:nən, ušẹ́sa - R ed.)

< ě pred $r$ (mẹ́ra, uẹ́rra, zuẹ:rr)

$<\mathrm{v}$ izposojenkah (žérgan 'blagoslov')

or: < $\quad$ q: (klọ:p, drọ̀:x 'drog', rọ̀:p 'rob', sọ̀tt 'sod', gouọ̀:p 'golob', mọ̀:šs 'mož')

$<$ kratki akutirani $Q$ v nezadnjih besednih zlogih (gọ́:ba, kọ́čca, tọ́:ča)

< novoakutirani $o$ v nezadnjih besednih zlogih (uọ́la 'volja', xọ́:ja, nọ́rša, škọ́:da, dọ́ta; nọ́ssam, prọ́ssam - 1. os. ed. sed.)

$<$ kratki naglašeni t (pó:ux 'polh', pò:uxan 'poln', dò'ux 'dolg' - prid.)

$<$ redko o:u < orv (koụọ̀rrat 'kolovrat')

$<\mathrm{v}$ izposojenkah (kọ̀rr 'kor')

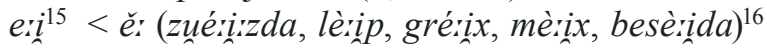

$<$ kratki akutirani ě v nezadnjih besednih zlogih (brériza, cérista, neuérista, stré:ixa, pé:ina, polé:in, ré:izate)

o: u $^{17}<$ cirkumflektirani or (nò'uč 'noč', mò'uč 'moč', rò̀ux 'rog', bò'ux 'bog', mesò'u 'meso', alpò'u 'lepo', prosò'u 'proso')

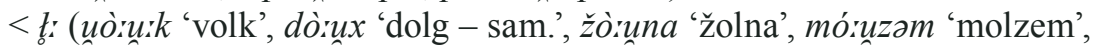
kó:unam 'kolnem', dó:ubam 'dolbem', tó:učam 'tolčem')

$<$ kratki akutirani ’ v nezadnjih besednih zlogih (pó:ux 'polh') ${ }^{18}$

$e_{s}: \quad<e$, ki je prišel pod naglas po premiku naglasa $\mathrm{s}$ končnega kratkega besednega zloga (žér:na, tẹ́:ta, čẹ:u 'čelo', nẹ́rsem - 1. os. ed. sed.)

$<e$, ki je prišel pod naglas po premiku naglasa s končnega kratkega besednega zloga (més:xka, tẹ́ršska, pẹ́:ta, klẹ́:čou - del. -l m. sp. ed.)

$<\check{e}$, ki je prišel pod naglas po premiku naglasa s končnega kratkega besednega zloga (uẹéža, žrẹ́:u, brẹ́:me, ựẹ́:me)

$15 »$ Na Dovjem, v Mojstrani in v okoliških vaseh (Belica, Podkuže, Zg. Radovina), a tudi v Planini pod Golico, v Plavškem Rovtu in v Prihodih se je podaljšani - $\bar{e}$ - diftongiziral v - ei (ei $i)$ - (kakor se je prav na istem področju -ọ- diftongiziral v -ou-); to lepo dokazujejo številna imena s tega področja /.../« (Čop 1983: 47)

${ }^{16} \mathrm{Na}$ Dovjem samo še nekateri najstarejši domačini ohranjajo dvoglasniški izgovor praslovanskega dolgega jata, a zelo nedosledno, večinoma se tu tako kot tudi v sosednjih gorenjskih vaseh že govori dolgi ozki ẹ: (snệ:x 'sneg', mlẹ́:k 'mleko', zvẹ́:zda 'zvezda', lẹ:p 'lep', grẹ́:x 'greh' itd.). Primer, ki ga je potrdila informantka z Dovjega M. Klinar: »A 'že snèrik dó:l pà:du? « V Plavškem Rovtu je refleks e: $i$ danes ohranjen le še leksikalizirano (inf. J. Klinar), npr. v besedah pérista 'pesto', strèriššnca 'strešnica, skodla', rèiztre 'reta' ( $\leftarrow$ bav. nem. Reiter) itd. K. Klinar navaja še primere kot: me i popé:istvou 'me je popestoval', snèizx je s stré:íxe pà:du 'sneg je s strehe padel'.

${ }^{17} \mathrm{~V}$ dovškem govoru je o: $u$ iz praslovanskega cirkumflektiranega $o$ danes ohranjem samo še leksikalizirano, npr. samò'utežne snì: 'samotežne sani' (kar poznajo tudi v Plavškem Rovtu), sicer se tu že govori monoftong kot v sosednjih gorenjskih govorih (prosọ̀: 'proso', nọ̀:č 'noč' itd.). K. Klinar za ơu v Plavškem Rovtu prav tako navaja le še leksikalizirane primere kot: 'pei má:u x mé:n u narò'uče ('pojdi/pridi malo k meni v naročje').

${ }^{18}$ V Plavškem Rovtu (inf. K. Klinar) npr. vó:una 'volna', dó:uga 'dolga' - prid. 
o: $\quad<o$, ki je prišel pod naglas po premiku naglasa $\mathrm{s}$ končnega kratkega besednega zloga (kó:tu, kớ:za, uó́ssa, kớ:nc, uó:nc)

$<$ q, ki je prišel pod naglas po premiku naglasa $\mathrm{s}$ končnega kratkega besednega zloga (sórset)

a: < a: (gràıt, pràxx, uràit, duà', krá:l, trá:ua, kouárč, brá:da, á:pən)

$<$ kratki akutirani $a$ v nezadnjih besednih zlogih (krá:ua, mástè 'mati', brá:ta - R ed.)

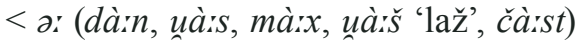

< novoakutirani a v nezadnjih besednih zlogih (má:ša, sá:ne 'sanje', pársjẹ, uàrške, 'vaški', premá:kne, páxxne, gá:ne - 3. os. ed. sed.)

$<\mathrm{v}$ izposojenkah (fá:inoštar 'župnik')

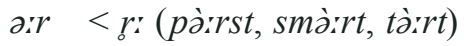

\subsubsection{Kratki naglašeni samoglasniki}

$i \quad<$ redko kratki naglašeni $i$ ( $\check{s}^{\prime} l i$ 'šli' - a pogosteje $\left.\check{s}^{\prime} l \partial\right)$

$u \quad<$ redko kratki naglašeni $u$ ('tut 'tudi')

$<$ kratki naglašeni -ěl v del. -l m. sp. ed. (m'lu 'mlel', cve'du'19 'cvedel')

$<$ kratki naglašeni $-i l \mathrm{v}$ del. $-l$ m. sp. ed. ( $p \partial x^{\prime} n u$ 'pahnil')

$<$ kratki naglašeni -al v del. $-l$ m. sp. ed. ('šu $u^{20}$ 'šel')

$e \quad<$ kratki naglašeni $e \check{v}$ zadnjem ali edinem besednem zlogu ( $\left.x^{\prime} r e n\right)$

$<$ kratki naglašeni $a \mathrm{v}$ zadnjem ali edinem besednem zlogu v položaju pred istozložnim $j$ oz. $i$ ('de ${ }^{21}$ 'daj' - 2. os. ed. vel.)

$o \quad<$ kratki naglašeni $u$ (preko a) v izglasju prid. in sam. v D, M ed. ( $t^{\prime} m o$, $p$ 'so 'psu')

es < novoakutirani $e \mathrm{v}$ zadnjem ali edinem besednem zlogu ( $\left.k^{\prime} m e ̨ t, \check{z}^{\prime} r e ̨ m\right)$

$<$ kratki naglašeni e v zadnjem ali edinem besednem zlogu ('uẹč)

$o<$ novoakutirani $o$ v zadnjem ali edinem besednem zlogu ('post, 'košs, 'kon, $k^{\prime}$ rop)

$<$ kratki naglašeni $Q$ v zadnjem ali edinem besednem zlogu ( $t^{\prime}$ rọk)

$<$ kratki naglašeni $a$ pred istozložnim $u$ v zadnjem ali edinem besednem zlogu (p'rou 'prav', zd'rou 'zdrav') 22

$a<$ kratki naglašeni $a \mathrm{v}$ zadnjem ali edinem besednem zlogu v izglasju (d'ga 'tega', šlua ${ }^{23}$ 'šla', gre'ua 'greva', məg'ua 'megla')

a < kratki naglašeni a v zadnjem ali edinem besednem zlogu ('pəs, 'təš 'tešč', 'uas 'ves', ste'bar)

${ }^{19}$ R. Razinger ima tu zapisan dolgi cirkumflektirani samoglasnik (cvedù: 'cvedel'). K. Klinar navaja različico $c u^{\prime} d u$ 'cvedel'.

${ }^{20} \mathrm{R}$. Razinger ima tu zapisan dolgi cirkumflektirani samoglasnik (šù: 'šel').

${ }^{21}$ R. Razinger ima tu zapisan dolgi cirkumflektirani samoglasnik (dẹ̀ri 'daj').

${ }^{22} \mathrm{R}$. Razinger ima tu zapisan dolgi cirkumflektirani samoglasnik (zdrò'u 'zdrav' in prò:u 'prav').

${ }^{23}$ R. Razinger ima tu zapisan dolgi cirkumflektirani samoglasnik (šùà: 'šla'). 
$<$ kratki naglašeni $i$ v zadnjem ali edinem zaprtem besednem zlogu ('nət

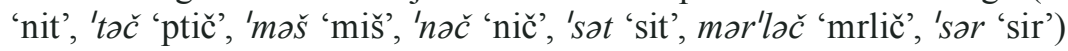

$<$ kratki naglašeni $u$ v zadnjem ali edinem zaprtem besednem zlogu ('krax 'kruh', 'kap 'kup', s'kap 'skup')

$<$ kratki naglašeni $a$ v zadnjem ali edinem zaprtem besednem zlogu ( $b^{\prime} r \partial t$ 'brat', 'gat 'gad', 'font 'fant', 'nəs 'nas')

\subsubsection{Nenaglašeni samoglasniki}

\subsubsection{Prednaglasni samoglasniki}

$i<$ včasih $i$ - po analogiji na naglasni položaj in disimilaciji z $a$-jem $\mathrm{v}$ naslednjem zlogu (pisà:ưa 'pisala', tiší: 'tišči', zidá:r)

$u \quad<$ (pluuástẹ 'pljuvati', klučà:ùnca 'ključavnica', dušìtẹ)

$<$ včasih vi (suná:k 'svinjak')

e $\quad<$ ě (lẹnós:ba ${ }^{24}$ lẹvíca, lesníka, plẹníca, snẹžèèn)

$o \quad<$ včasih $o$ (očì' 'oči')

$e \quad<e$ (nebò:u 'nebo', zelẹ́:no, uesẹ̀:ua 'vesela', letí', besèrida 'beseda', telẹ́:ta) $<$ e (mesò:u, pesti: $)$

$<$ redko o za $r$ (precèrisja 'procesija')

$o \quad<o$ (gouọ:p 'golob', otrọ̀:k)

$<q$ (zobjẹ: $)$

$<$ redko to (do'žon 'dolžan')

$a<a$ (puačá:te 'plačati')

$<e$ (a'don aク'ga 'eden enega')

ə $\quad<$ ə (məg'ua 'megla', stəz'da 'steza', 25 stə'bər 'steber', $p \partial^{\prime} k u$ 'pekel')

< redko u (stadẹ:nc 'studenec')

$<$ redko ě (cuət'na 'cvetna')

$<$ prednaglasni $r$ pred soglasnikom skupaj z $r(\partial+r)$ (parstì: 'prsti' - R ed. ž. sp.)

\subsubsection{Ponaglasni samoglasniki v zaprtem zlogu}

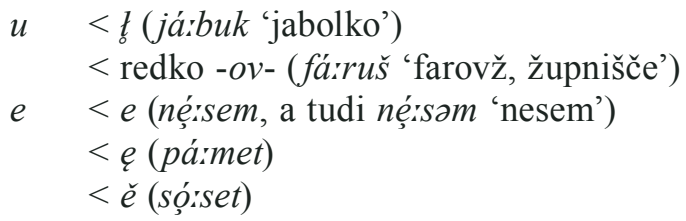

${ }^{24}$ K. Klinar za Plavški Rovt pozna le različico alnó:ba 'lenoba' s popolno onemitvijo prednaglasnega jata.

${ }^{25}$ K. Klinar za Plavški Rovt pozna le različico stz'za 'steza' $(<* s t b d z a ̈)$. O nastanku različice staz'da piše Ramovš (1924: 223). Glej še Šivic-Dular 2007. 
$<a$ pred istozložnim j/i (dé:inuei 'delaj' - vel., 2. os. ed.), redko drugje (smẹ́tena 'smetana')

$<i \mathrm{v}$ priponi -nik (uórsounek 'oselnik', toda tudi kù:rnek ${ }^{26}$ 'kurnik')

$o \quad<$ včasih $a$ pred $v$ (bradovícca 'bradavica')

$<a$ pred istozložnim $u \mathrm{v}$ del. -l (dé:ícuou 'delal' - 3. os. ed. m. sp.)

$a<a$ (žàrgat(è) 'žagati', dérinatè 'delati')

< o (járgada 'jagoda', ná:xat 'nahod', pọ́:tak 'potok', brìtaf 'pokopališče')

a < ə (xuà:pac 'hlapec', xlẹ:bac 'hlebec', kó:sac 'kosec', pé:insak 'pesek', pẹ́:tak 'petek')

< $i$ (xọ́ddam 'hodim', prọ́ssam 'prosim' - sed., 1. os. ed.; jẹ́zzək 'jezik', prế:ššč 'prašič’; par ušẹ̀ssax 'pri ušesih' - sam., M mn.)

$<u$ (trérínbax 'trebuh', kó:žax 'kožuh')

$<\check{e}$ (uí:dat 'videti')

< redko e (nẹersem/nẹersam 'nesem', zẹ́:lan 'zelen')

\subsubsection{Izglasni samoglasniki}

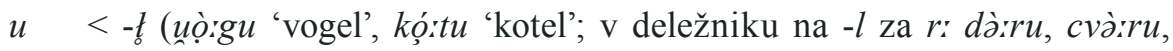
ưm̀̀:ru, ž̀̀ıru)

$<-e v$ (plítu 'plitev', cẹ́:rku 'cerkev')

$<-v i$ (ta pàrru 'prvi')

$<-$ vo (kuá:du 'kladivo')

$<-l o$ (gá:ru 'grlo')

$<-e ̌ l$ v del. -l (ž́ruu 'živel')

$<-e l$ v del. -l (uóótu 'hotel', uéridu 'vedel')

$<-i l$ v del. $-l$ (uzírgnu 'vzdignil')

ele < - $i$ (v nedoločniku: zdéritè 'sedeti', grabìtè 'grabiti' in pstìte 'pustiti'; nọ́ssè - 3. os. ed. sed.; má:tè 'mati’; gù:nè 'oni’; na mízzè - M ed. ž. sp.; z ženà:mé - O mn. ž. sp.; s fà:ntè, z lèritiè 'z let' - O ed. m., sr. sp.; v določni prid. prip.: člouèrške, martuárške, túrrške, nebèrškẹ; trẹ́:tjẹ; v prisl.: górre 'gori', dó:le 'doli', nọ́trẹ 'notri')

$e \quad<-e$ (pọ̀lle 'polje’, mọ̀rje, nẹ́rse, tẹ́:če, pẹ́:če)

< -e (tẹ́lle; mírze - R ed. ž. sp., fá:nte - T mn. m. sp.)

$\dot{o} / o<-u$ (brá:to 'bratu', sìno 'sinu', nò:uso 'nosu'; po méristọ 'po mestu', u sè:no 'v senu' - D, M ed. sam., prid. m., sr. sp.)

$o \quad<-o$ (lí:po, mírzo - T ed. ž. sp.)

$a<-a$ (járgada 'jagoda', guárua ${ }^{27}$ xrùıška 'hruška', krá:una - I ed. ž. sp.)

${ }^{26}$ R. Razinger ima tu zapisan ozki e (kù̀rnẹk).

${ }^{27}$ R. Razinger ima dvakrat zapisano glá:ua (I ed.) in enkrat gualẹ̣: (R ed.). 


\subsection{Soglasniki}

Soglasniki so nastali iz ustreznih soglasnikov v izhodiščnem splošnoslovenskem sistemu, ob tem pa še:

\subsubsection{Zvočniki}

u <w pred sprednjimi (uílle 'vile', uí:n 'vino', uečẹèrja 'večerja') in zadnjimi samoglasniki (uó:la 'volja', suà:p 'slap', uò:rx 'vrh', pó:tpuat 'podplat') $)^{28}$ $<$ kot proteza pred zadnjimi samoglasniki v vzglasju (uó́:kən 'okno’, uọ̀rrgle 'orgle', uórsua 'osla', uó́:uca 'ovca')

$<l$ pred zadnjimi samoglasniki - švapanje (uàrs 'las', m'uət 'mlad', koụọ:rat 'kolovrat', duá:ka 'dlaka', dèrinoua 'delala', può̀ut 'plot') ${ }^{29}$

$<-l$ v izglasju (v del. - $l$ dériuou 'delal', bìru 'bil'), tudi - $l$ pred izglasnim o po onemitvi le-tega (kadí:u 'kadilo', čeśru ‘čelo', šíu ‘šilo', dẹ́ru 'delo')

$l \quad<$ l (stẹ̀:la 'stelja', krá:l 'kralj', zẹ́:mla 'zemlja', klú:č 'ključ', uọ́:la 'volja', peláste 'peljati')

< po analogični menjavi med $l$ in v (cẹ́rkle 'cerkve', gualẹ: 'glave', stàrtle 'statve') $)^{30}$

$n \quad<$ ń (órgan 'ogenj', sví:na 'svinja', ní:ua 'njiva', korẹ́:ne 'korenje', kam'nẹ 'kamenje', lobá:na 'lobanja')

$j(i)<$ redko kot proteza pred sprednjimi samoglasniki (iiglíca 'igo')

$<$ včasih kot prehodni $j$ pred sičniki in šumevci (ú:inzda 'uzda', pàrisxa 'pazduha', pọ́:ístla 'postelja', 'goist 'gozd') - a tudi pàrstxa 'pazduha' $<$ redko $g$ pred sprednjimi samoglasniki - narečna palatalizacija velarov ${ }^{31}$ (drùriga 'drugega', Dò̀uje < dolge) - toda nogẹ:' 'noge'32

$r \quad<$ redko kot epentetični/vrinjeni $r$ (faržò'u 'fižol', faržìina 'kovačnica, fužina')

${ }^{28}$ Danes na Dovjem na tem mestu (sicer nedosledno) že govorijo tudi zobnoustnični $v$, npr. sam vídva 'sem videla'.

${ }^{29}$ Švapanje je skupna lastnost vsem tu obravnavanim govorom, npr. pràzua je 'prala je', kuà:l smo 'klali smo'. V Plavškem Rovtu (inf. K. Klinar) je možna tudi asimilacija lo $>$ uo (švapanje) $>o$, in sicer tako v naglašenem (kó:bək 'klobuk') kot v nenaglašenem zlogu (kobá:sa 'klobasa'). Primer take asimilacije z Dovjega: godá:te 'glodati'.

${ }^{30}$ Primer iz Plavškega Rovta: potklẹ: 'podkve'.

31 »Palatalizacije velarov ni bilo na Dovjem, v Mojstrani, Zg. Radovini, deloma na Belici in v Podkužah. To velja predvsem za velarna glasova $-k$ - in $-x$-, medtem ko - $g$-, verjetno pod vplivom sosednjih gorenjskih govorov (Gorje, Jesenice) do neke mere vendarle kaže prehod $\mathrm{v}-j-/ . . /$. Če pravim, da $\mathrm{v}$ imenovanih krajih ni bilo palatalizacije velarov, mislim pri tem na starejši rod domačinov, medtem ko mlajši rod v celoti prevzema gorenjsko palatalizacijo /.../, da ne govorim o številnih priseljencih iz zgornjega dela Doline, ki seveda ohranjajo svoj način govora z nepopolno palatalizacijo velarov« (Čop 1983: 69).

${ }^{32}$ Informatorka M. Klinar z Dovjega se še spominja, da so nekoč rekli »u nọ̀yje me zẹ́be«, a sama danes ne govori več tako. 


\subsubsection{Nezvočniki}

$b<p$ po disimilaciji $p-p>p-b$ (pọ̀:bək 'popek')

$t<$ redko $k$ pred sprednjimi samoglasniki - narečna palatalizacija velarov ${ }^{33}$ (tìkla 'kikla, krilo', tíssalca 'kislica', tí:mnata 'čumnata', verjetno iz nem. Kemenate $\longleftarrow$ slat. caminata (Snoj 2003: 92)) - toda rokẹ: 'roke', kẹ́:udor 'klet'34

$<k j$ pred sprednjimi samoglasniki (téri 'kje')

$\check{s}<\operatorname{redko} x$ pred sprednjimi samoglasniki - narečna palatalizacija velarov (mešẹ:r 'mehur') - toda uré:inxe 'orehe', múxxe 'muhe'

$<\check{c}$ pred $k$ (disimilacija čk $>\check{s} k$ ) (màrška 'mačka', bárške 'bačke, butare' - T $\mathrm{mn}.)^{35}$

$\check{c}<$ po asimilaciji tč ( $>$ dč $)$ (razrẹ́rčst 'razredčiti').

$g<$ redko kot (sekundarna) proteza pred $u$ v vzglasju (gù:nedua 'onadva')

$x<$ redko $t(<d)$ pred $k$ (asimilacija $d k>x k$ ) (síraxka 'sirotka') - toda suástka 'sladka', rérítka 'redka', pọ́ttkua 'podkev', póttpuat 'podplat', otprérínte 'odpreti'

< izglasni -g (brè̀ịx, drọ̀xx, snèrinx, stọ̀:x 'kozolec')

\subsection{Naglas}

5.3.1 Naglasno mesto $\mathrm{v}$ besedi je kot $\mathrm{v}$ izhodiščnem sistemu, le da sta naglašena refleksa za $e$ in $o$, ki sta bila prej pred naglašenimi kratkimi zadnjimi zlogi, npr. séristra (< sestrá), kósisa $(<k o s a ́)$.

5.3.2 Kvantiteta je kot v izhodiščnem sistemu z naslednjimi razlikami:

5.3.2.1 Dolgi so samoglasniki, ki so bili kratki naglašeni (akutirani) v nezadnjih besednih zlogih (krá:ưa).

5.3.2.2 Dolgi so samoglasniki po umiku naglasa s končnega kratkega zloga na prednaglasna $e$ in $o$ (sẹ́rstra, kórsa).

5.3.3 Tonematika je kot $\mathrm{v}$ izhodiščnem sistemu $\mathrm{z}$ naslednjimi razlikami:

V́: < po podaljšavi kratkega akuta v nezadnjem besednem zlogu (krá:ua)

$<$ po podaljšavi novega akuta v nezadnjem besednem zlogu (kọ́:ža)

$<$ po umiku naglasa s kratkega končnega zloga na prednaglasna $e$ in $o$ (tẹ́ta, gós:ra)

33 »Na Dovjem, v Mojstrani itd. se namreč - $k$ - ni palataliziral, ampak se je ohranil kot $k$ tudi pred $e, e$ in $i$ oz. ga je v določenih primerih (predvsem na začetku besede) zamenjal -t- (trdi - $t$-, ne palatalizirani - $t$ '-), kar je do neke mere vendarle vpliv gorenjske oz. še prej ziljsko-koroške palatalizacije: priseljenci niso zmogli izreke $-\check{c}$ - oz. $-\dot{c}-,-t t^{\prime}-<-k$ - in ta glas nadomestili s $-t-$ ) /.../« (Čop 1983: 69).

${ }^{34}$ V Plavškem Rovtu, Žerjavcu, Belci narečno mehčanje mehkonebnika $k$ pred sprednjimi samoglasniki v $\check{c}(k>\check{c})$ še poznajo (npr. čésudar 'kevder, klet', ščírra 'sekira'), na Dovjem pa govorijo le kẹ́rudar, skíra, nogẹ̀: itd., saj ta govor (danes) ne pozna narečne palatalizacije velarov/mehčanja mehkonebnikov.

${ }^{35}$ Primera sta s Plavškega Rovta (inf. K. Klinar). 
$\grave{\mathrm{V}}: \quad<$ stari cirkumfleks (lìst)

' $\mathrm{V}<$ naglašeni samoglasnik $\mathrm{v}$ zadnjem ali edinem besednem zlogu - novi kratki akut v prvotno zadnjem ali edinem besednem zlogu ('kon 'konj', 'məš 'miš')

$\mathrm{V}<$ nenaglašeni samoglasnik (želéịis 'železo')

$<$ 'V po umiku naglasa s končnega kratkega naglašenega samoglasnika (uọ́ssa 'osa')

\section{Izguba glasov}

\subsection{Samoglasniki}

$i \quad-\mathrm{v}$ prednaglasnih zlogih (3'gan 'cigan', srò'uta 'sirota', š'rọk 'širok', u'sok 'visok', tarjẹ̀: 'trije', parjà:tu 'prijatelj', žuésite 'živeti')

- v ponaglasnih zaprtih zlogih ( prídga 'pridiga', precè̀isja 'procesija'; uọ́šspce 'ošpice', pá:lca 'palica', guá:žena 'glaževina, steklo', jệitka 'jetika', lé:iššnk 'lešnik', grá:ft 'grabiti'; muá:tta 'mlatita')

- v izglasju: redko v nedoločniku (uídat 'videti', smejá:t se 'smejati se', stegni:t se 'stegniti se, umreti'); včasih v D, M ed. sam., prid. ž. sp. (nóx:x/nớ:ge 'nogi', na usóóke gó́r(e) 'na visoki gori');36 v prid. priponi $-n i(<-b n ъ-j-b)$ oz. -nji $(<-b n ́ b-j-b)$, npr. v I ed. (kàrrstən 'krstni', ta $z a ̀$ àdən 'sprednji')

u - v prednaglasnih zlogih (ššìte 'sušiti', pstìite 'pustiti', alpì̀ua 'lupila', tlìua 'tulila', kpìua 'kupila')

- včasih v izglasju (na uoó:kno/na uoó:kan 'na oknu', par dnẹ:u 'pri dnevu, podnevi', blí:s 'blizu')

$e(<\check{e})$ - v prednaglasnih zlogih (snò'u 'seno', čpína ‘črepinja', zdérite 'sedeti', dəruò̀u 'enojni plug, drevo', sjà̀té 'sejati'; v prid. končnici -ěga ( $a \eta^{\prime} g a /$ әฤ'ga 'enega'), -е̌mu (әn'mọ 'enemu')

- v ponaglasnih zlogih (uố:rxx 'oreh'; v prid. končnici -ěga (drù̀iga 'drugega', usó:gra 'visokega'), -е̌mu (usó́kmo 'visokemu'); v glag. priponi -ě- v sed. mn., dv. (uọ́rčta 'hočeta'), v del. -l (uí:dúa 'videla', uó:tua 'hotela')

o $\quad$ - v prednaglasnih zlogih (əncọ́: 'nocoj')

- v ponaglasnih zlogih (bínkšte 'binkošti')

- v izglasju v I ed. sr. sp. - maskulinizacija nevter (čẹ́:u ‘čelo', stẹ́:gan 'stegno', kolé:in 'koleno', uí:n 'vino', ží: 'žito')

ə - v prednaglasnih zlogih (kè̀re 'kateri')

- v ponaglasnih zlogih (dó́:ns 'danes'; v priponi -ac (kó́:nc 'konec', pà:uc 'palec', marjá:sc 'merjasec', komò̀zuc 'komolec', mè̀isc 'mesec'); v priponi -ək (tọ́rk 'torek'))

a $\quad$ - v prednaglasnih zlogih (sni: 'sani')

${ }^{36}$ K. Klinar v Plavškem Rovtu: un kàršt 'v leseni skrinji za žito'. 


\subsection{Soglasniki}

6.2.1 V sklopu $p t$ - se je $p$ včasih reduciral ('təč 'ptič').

6.2.2 $a d v$ - > včasih uof-, pri čemer je $u$ - proteza (uo'fant 'advent').

6.2.3 Skupina -šč- se je obrusila v -š- (i:šem 'iščem', ogníšse 'ognišče', gọ́:ša 'gošča, gozd', na te'še 'na tešč', klé:ǐše 'klešče').

6.2.4 V skupini črě, žrě je /r/ navadno izpadel (že'bal 'žebelj', žbe 'žrebe', žèri $b a c$ 'žrebec', žbẹ̀:tək 'žrebetek', čèrual ‘čevelj', čè̀išna ‘češnja', čé:ua ‘čreva', čpí:na 'črepinja') - toda črérínsu 'čreslo'.

6.2.5 V sklopu $/ d n /$ je /d/ izpadel (zapò:una 'dopoldne', opò̀une 'opoldne', popò:une 'popoldne').

6.2.6 V sklopu/td/ se je /t/ asimiliral z /d/ v en glas (pẹ:deset 'petdeset', šẹ:deset 'šestdeset').

6.2.7 V sklopu $t v$-, $s v$ - (v zaimkih) se /v/ ne govori (tọ́ri tóriga ... 'tvoj, tvojega ...', sọ́ri sóriga ... 'svoj svojega ...').

\subsection{Druge posebnosti}

6.3.1 Metateza ogn-> gon- (goníše 'ognjišče').

6.3.2 Značilna je tvorba prislovov brez -j (zá:da 'zadaj', znọ́:tra 'znotraj', spọ́:da 'spodaj', zgọ:'da 'zgodaj').

\section{Besedila}

\subsection{Dovje B $^{37}$}

»'Jes 'tud velíkrá:tou na fá:nta govarí:m. Mì: smo domà: na fá:nta. Pa 'tut, 'no, tkọ̀lle drù̀k še tùrt. A'ne, 'zeị tìsst $k$ so šlli 'bal u šọ̀lle pa u Lublá:no pa tọ̀: pa študìrat so 'bal šli, a'ne, da so lepọ̀ goụọ̀rral. Tá:kle k pa nísmo, k smo 'bal domà: ustáll, se m pa zdí', da pa rẹ̀ss učàisax 'kar nẹ́keị po suórjam. /.../«

»Sírk smo lušill, recìmo tkò:le, pózím, pó:i, u jesẹ̀n smo ga ulìčkal pa poctrẹ̀ršno nérsal, da se i pošùišu, pór smo ga pa dó:l parnérsal, da smo ga ulú:šal. I.../ Pozí:m, k je biu '̌̀ss, je pa á:ta naštírmou tá:ko kìšto. Pó: i biu pa tkọ̀lla n tá:k kọlọ̀, da se i uərtẹ́:u, pa n zobẹ̀: so bli, da se i tọ̀ lú:šso. Pó: pa ní: se ưse udlúišuo, se i pa na rọ̀ze mọ̀gal. /... Tkọ̀r s tìrsto špíčcko odló:mu, pa si s tọ̀: špí:čko dárrgnu, da z do kónnca /.../ Tọ̀: i čùrrčal.»

»Tọ̀: se pa ̌̌e 'jes spò:unom, $k$ sam bua še ut'rok, smo mì mẹ́l xlà:pce pa dẹ́:kle. A'ne, tọ̀ so paršlì dó:l z Dólẹ́:nzga, ponavá:t so bla z Dólẹ́:nzga. 'Ja, pa 'tut s Primọ̀rske, to mlá:di fá:ntje pa pùince, $k$ domá: níso îmẹ́rl, $k$ so ble tẹ̀: kà̀iže pa uelík otrọ́:k pa níso mẹ́ll dóma 'nəč, so ta pàrru pəršlì: na kmẹ̀tte, pó: so pa sevẹ:a na Isenícax, $k$ je bua fá:bərka, so pa póri pómagá:l pa u

${ }^{37}$ Informantka za govor Dovjega: Marjana Klinar, 1949. 
fáabarko xódíl u slù:žbo. I.../ K'le so pa pó:i, k'le i bua učàssax kà:mra, mì: smo ré:kal uẹ̀:žna kàrmra in 'tù:ka so ble pọ̀tistle, é:don al 'pa dvàr: xlà:pca sta klé:le ležá:ua, mì smo kú:xno 'tamle mẹ́ll, pò:u mà:nšo. Skọ̀ss smo imẹ́:l dẹ́:kle pa xlà:pce, 'ja. Pa še gó:r na vàrrx na ué:šs smo ịmẹ́:l 'tut postlá:n, je biu é:don s Primọ̀rrzga 'tut, ar, léržou gó:r. 'No, pór so pa é:n so šlla čez mérjo pa so šlli 'tut, é:n je 'šu na Šuẹ̀rck /.... Póri so pa sami: 'tud začẹe:l že 'kəšne xíše dẹ́llat, 'ja. /.../«

»G'rem na tí:mnato. 'Tam smo pa sprauláll, káš̌ča za žít, pa mesọ̀r se i sprá:un, a'ne, $k$ se i póšùišu u tẹ̀:lax ràrufkà:mrax pa so mèsọ̀: póri sprá:val u tí:mnato, 'no, par 'nas je bua tọ̀ zgọ̀rna špà:iza. Pó: so tkọ̀r mẹ́l narjé:n, a'ne, da se i tọ̀ ubẹ́suo, da se i šušìn na zrà:ko 'še. Ó:kan je biu, skọ̀s je mọ̀gu bit otpàrrt, da i biu z'rok /...l. Pa póri táke stvarì̀ i bo tọ̀: spràzulen, za kuàrne, recìmo tá:ka posọ̀dda, pískri, pa màsst se i spráruua górr, žít, 'ja. Pór smo pa u ží:t 'tut járicica dajà:l, da so se sprázule, I.../ da so 'dal tràijale. I.../

»/.../ Pa má:žəlne smo narẹ̀:dla. (Kaj pa je to?) Má:žəlnè so pa s kárše. Prosẹ́:na ká:ša, pa glaví:na, pó: pa začìmbe 'tut. Pó: s pa tá:ke kù:pčke narẹ̀:du, tá:ke kẹ́:pce, krùrgalce, 'no. Pó: se i pa tà: kùrgalca poví́va u mrẹ́:no, ot prešíča tàr mrẹéna. Pór se pa tọ̀, spérčeš u rọ̀rro.«

»'Bal se za lànn spò̀mnam. Smo pózéśl, pó: se i pa na mé:jo dá:u, da se i pósùršvo, čìst na tejkọ̀: s mọ̀gu tkọ̀: porazdelít, pozzệ́t, pa s po méri possùršu, pó: se i pa tọ̀ tàrrvo, 'ja. Mẹ́l so pa za, 'tamle górr na ré:bro so ré:kal, da so tz̀:ral. Tọ̀: i bvo tá:k, da se i zakùrrvo, se i 'tam spẹ̀:t posùršu. /.../«

\subsection{Plavški Rovt ${ }^{38}$}

»Čú:mnata je bua pa špà:iza. I.../ Par 'nəs je bua mè̀ixən po štẹ̀:ygax gó:r, par Martìnc górr je bua pa 'koi naglìxo 'ke zmẹ̀rreî. Par'nas je biu pa kẹ́:udar 'tam,

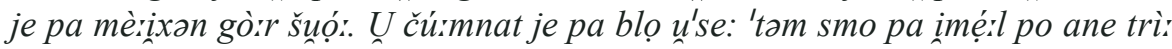
sọdòue po ane trìsto lítrou, smo mó:št dẹ́rual, 'no, pó: i bua pa ena kọ̀šta, a uẹ́:šs, kuá: i bua kọ̀šsta? (Ne.) Kọ̀ršta so ré:kal, $k$ so žít nọ́ttar u ná:dalne metárl. I.../ Pa da níso má:čk paršlla pa da níso pregodá:l. I.../ Je bua kukər xíša širó:ka čú:mnata, uelìka. /.../ Ćú:mnata i 'bal po rò:utarsk 'bal, k'le pa pràrujo tímnata, na Dò:ujam. I... 'No, k'le i biu pa uó:kən pa 'təm an uó:kan, kukar je bua xíša širó:ka, pa gá:utre nó:tar, a'ne, zazí:dan u tìssto, tokọ̀:, želẹ́zzje, a'ne, tkọ̀: mó:čno, 'bal màrìxne uọ́:kna so ble. 'Tam je bua pa 'še na skrína, 'še na tá:ka kọ̀ršta, par t'mo kráija 'sam so bli pa 'mau mànn ná:dəlné. Tọ̀r smo pa še, če smo tọ̆:le mlẹ́ll, otrọ̀:be pa mọ́:ko ta korùzzno pa tá:k so nọ́:t nardíl, da ní: buo úse ucpó:da, né:kei pa ucpó:da, a'ne. Póri smo pa 'še górr ịmẹ́lle na ù̀rrx, tọ̀ i buo pa tọ̀:le pó:i uẹ́:lbano, pa ucpó:da uẹ́:lbano, na ù̀rrx je bua pa 'še na tí:mnata, 'še na čúumnata glìx tkọ̀: ulì̀ka. Tìsta i bua pa 'tut tkọ: 'mau 'bal zapšé:na 'tud

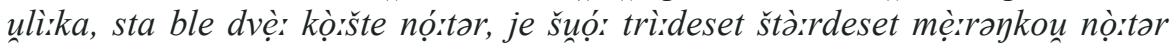

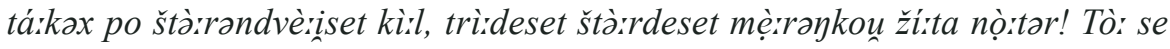

${ }^{38}$ Informant za govor Plavškega Rovta: Jože Klinar, rojen 1927 (od poroke živi na Belci). 
pràru desẹ̀rt, je tàzužznt kìl je buo nọ́t žíta. Pó: so pa untpìral tkọ̀r, pa má:u je blo tkọ: predelé:n. Òxx, tọ̀: s kò:ma nọ̀t zlè:zu, pa na guá:uo. So bli širó:k ná:dalni. I... Pa kọ́: i fàrin guẹ́rrou nọ́tar, pa polẹ́:t mẹsọ:. Je skọrz uírsu, pa unbè:ne múxxe nọ́tar. Je bua 'mau 'bal tmàr, uẹ́ršs, 'tom. /.../ Tọ: i buo uzárda, $k$ je buo u sẹ̀:nc. /.../«

"Tọ̀r so pa snì: Rọ̀ddal. /.../ 'Jes sam jax i'mu, 'jes sam pa póri sàıykou. 'Jes sam biu u Šuìc na suẹtọ:uanmo paruẹ:nstuo. (Ste bili?) U Dàruoso. (A res?!) 'Ja. Sẹ́:dompẹ:desedga lẹ́ta. (V jugoslovanski reprezentanci?) Jàr! Smo k'lele smo bli ... Pa sérstra i bua, tàr $k$ je na Insenícax pa 'še 'dan z Jesenìc, tarjẹ:

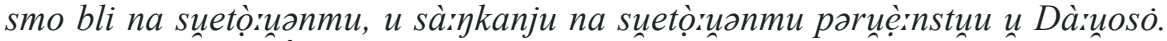
(Bravo!) Pó: pa u Àustrii na dəržá:uənmo paruẹ̀nstuu, smo ulík xodíl tak'rat ukrọ̀x, še nísam biu k'lele. 'Ja. Pó: pa nísam 'ueč, $k$ som 'šu z Rórutou. Pa mó:ja sérstra, sua bua zmẹ̀rrei ta pòrrua $k$ smo bli tkọ̀: nauàrjen tẹ̀rga sà:ykana,

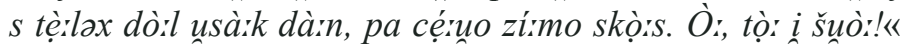

\section{3 Žerjavec nad Jesenicami ${ }^{39}$}

»'No, 'jes se še spòrmnam k sam biu tá:k fan'təč, sam uó:zu z Gólíce snọ̀:. Pólẹ́rt, s ta pàrrumo kónncam, zá:dei pa žlárife pa nabàrsan. 'Tam k ní: šlọ s cẹ́:umo uọ̀zzam, 'ne, i blo tkọ̀r starmọ̀', da ní:s mọ́rgu s cẹ́:umu uọ̀zzm, ampak $s$ ta pàrrumo dẹ́lam. Póri i blo pa lepọ: társa nabàrsna, pó: so pa ucpórdei dó:l mozzàakarje čaká:l in so uzírganli pa na ta zàrdon kó:nc dàrl. Pa se i spẹ̀:t napréri peláru. Tkọ̀r so fùrral, 'no, da se i čìrm 'mon dẹ́rua pa čìmm 'bal tkộr. I. ../«

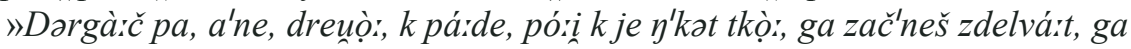

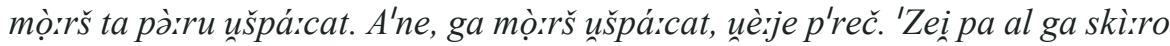
al ga z žàrgo ušpárcaš. 'No, 'zei na žàrgo že špárcamo, učàrsax smo pa tọ̀ úse s skìro, a'ne. Prẹ̀:x je bua gù:na, 'no, kọ̀: smo že ré:kal tẹ̀ll žà:x ... amerikàyka.

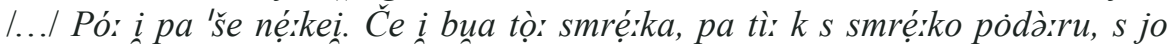
mọ̀gu umárit, ǔšpárcat, pór s jo pa unà̀:ju, lú:bje p'reč. In učàrsox so ga na mẹ́:tar, ga i zarẹ́:zou in $k$ se i má:ju l...l, s kọ:žarjom z ga unáiju in tìsst črẹ́:su se i póri pósùišu. Tọ̀ so ga póri dórl so ga vózíll za za ... lú:ženje ... tìst črẹ́rsu, za strojì:t /.../ da so lùržal s tìsstmo črẹ́rsuam, a'ne. Tọ̀: so ứse ponùrcal. Ue:je so pa póri póbráal tárk k níso do'ma doruár îmẹ́rl, tkọ: da i bua gmàizna čìsta. /.../ Crẹ́:su i biu samọ: ut smrệ:ke, ker samọ: tàr se i umá:ju, drùxx pa 'ne. /.../

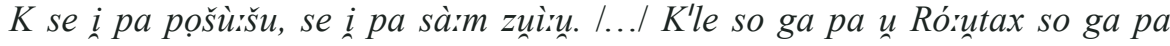
uélík zuózíl. /.../«

\section{Sklep}

Govor Dovjega je po svojih glasoslovnih značilnostih gorenjski govor, ki ima zaradi tesnih vsakodnevnih povezav in migracij prebivalstva $\mathrm{v}$ sosednje in

${ }^{39}$ Informant za govor Žerjavca nad Jesenicami: Maks Klinar, rojen 1943. 
večje gorenjske kraje vedno manj lokalnih (krajevnih) jezikovnih posebnosti in vedno več skupnih značilnosti s sosednjimi gorenjskimi krajevnimi govori. Med najbolj opaznimi značilnostmi tega krajevnega govora, večkrat predstavljenega tudi $\mathrm{v}$ jezikoslovni literaturi, je dvoglasniški refleks praslovanskega jata in cirkumflektiranega $o(e: i$ in $o: u$ ), ki pa sta danes tako na Dovjem kot v sosednjih vaseh ohranjena le še v leksikalizirani obliki in nista več sistemska. Podobno velja tudi za narečno mehčanje mehkonebnikov, ki je v sosednjih govorih še precej izrazito, na Dovjem pa veliko manj dosledno. Druge tipične gorenjske narečne značilnosti v razvoju samoglasnikov in soglasnikov so tu še zelo dobro ohranjene.

Zanimivo je tudi besedje in oblikoslovna ravnina tu obravnavanih gorenjskih govorov, kar pa je v članku le nakazano s kratkimi besedili in na tem mestu še ni jezikoslovno analizirano.

\section{LITERATURA IN VIRI}

Dušan ČOP, 1983: Imenoslovje zgornjesavskih dolin: disertacija. Ljubljana.

--, 1991: Imenoslovje jeseniške občine. Jeklo in ljudje 6, 61-71.

- -, 1995: Imena krajev v jeseniški občini in njihov izvor. Jeseniški zbornik, 161-171.

Marc L. GREENBERG, 2002: Zgodovinsko glasoslovje slovenskega jezika. Maribor: 2002. (Prevod izvirnika: M. L. Greenberg, A Historical Phonology of the Slovene Language. Heidelberg, 2000.)

Silvo TORKAR, Silvo, Metka FURLAN, Janez KEBER, Alenka ŠIVIC-DULAR (ur.), 2007: Merkujev zbornik, Jezikoslovni zapiski 13, 1/2. Ljubljana.

Tine LOGAR, 1954: Dialektična podoba Zgornjesavske doline. Slavistična revija 5-7, 145-149. (Kot poglavje z naslovom Narečna podoba Zgornjesavske doline ponovno objavljeno v: Dialektološke in jezikovnozgodovinske razprave, ur. Karmen Kenda-Jež. Ljubljana 1996, 40-43.)

- -, 1962/63: Današnje stanje in naloge slovenske dialektologije. Jezik in slovstvo 8, $1-6,307-312$.

--, 1981: Izhodiščni splošnoslovenski fonološki sistem. Fonološki opisi srpskohrvatskih Ihrvatskosrpskih, slovenačkih i makedonskih govora, obuhvačenih opšteslovenskim lingvističkim atlasom. Sarajevo: 1981, 29-33. (Ponovno objavljeno v: Dialektološke in jezikovnozgodovinske razprave, ur. Karmen Kenda-Jež. Ljubljana 1996, 243-247.)

- -, 1996: Dialektološke in jezikovnozgodovinske razprave. Ur. Karmen Kenda-Jež. Ljubljana.

Regina RAZINGER, 1967: Govor vasi Dovje. Rokopis, nastal pod mentorstvom prof. Tineta Logarja na Filozofski fakulteti v Ljubljani, shranjen v arhivu Dialektološke sekcije ISJ FR ZRC SAZU. Ljubljana. 
Jakob RIGLER, 1963: Pregled osnovnih razvojnih etap v slovenskem vokalizmu. Slavistična revija 14, 1-4, 25-78. (Ponovno objavljeno v: Zbrani spisi I. Jezikovnozgodovinske in dialektološke razprave, ur. Vera Smole. Ljubljana 2001, 13-57.)

- -, 1967: Pripombe k Pregledu osnovnih razvojnih etap v slovenskem vokalizmu I. Slavistična revija 15, 1-2, 129-152. (Ponovno objavljeno v: Zbrani spisi I. Jezikovnozgodovinske in dialektološke razprave, ur. Vera Smole. Ljubljana 2001, 58-76.)

- -, 2001: Zbrani spisi I. Jezikovnozgodovinske in dialektološke razprave. Ur. Vera Smole. Ljubljana.

Marko SNOJ, 2003: Slovenski etimološki slovar. Ljubljana.

Alenka ŠIVIC-DULAR, 2007: Psl. *stegna v slovenskih govorih. Merkujev zbornik (Jezikoslovni zapiski 13, 1/2), 429-440.

Jožica ŠKOFIC, 1997: Fonološki opis govora Krope (SLA 202). Jezikoslovni zapiski 3, $175-189$.

- -, 1999: Fonološki opis govora kraja Zgornje Gorje (SLA 198). Jezikoslovni zapiski $5,183-195$.

- -, 2000: Fonološki opis govora kraja Lom pod Storžičem (SLA 204). Jezikoslovni zapiski 6, 141-154.

\section{PHONOLOGICAL DESCRIPTION OF THE DOVJE LOCAL DIALECT}

The article presents the phonological description of the local dialect of Dovje (SLA T195) in Upper Carniola (Gorenjska), compared with some other neighbouring local dialects. The article contains an inventory of phonemes and prosodemes of this dialect, describes their distribution and explains their origin.

The speech has a monophthongal-diphthongal vowel system. The quantitative opposition (long stressed, short stressed and short unstressed vowels) is preserved - there are also intonation oppositions on long stressed vowels. Either long or short stressed vowels can occur in any syllable. All Slovene stress-shifts have occurred in this dialect. The vowel system of Dovje local dialect consists of the following long stressed vowels: ' $i$;, 'é, 'er, 'ar, 'or, 'or, 'ur, 'arr, but also 'eri (<*ěe, for example plériša 'pleša') and 'oru (<*ô, for example nò'us 'nos'); short stressed and unstressed vowels are exposed to strong dialect reduction. The consonant system (of voiced and voiceless consonants) is similar to that of the standard language except for the distribution of consonants. The voiceless consonants assimilate to the following consonant, in word-final position only voiceless consonants can occur. Also typical for the Upper Carniolan dialect is the hardening of $l$ into $l$ and $n$ into $n$. Various consonant changes also occur (assimilation, dissimilation, differentia-

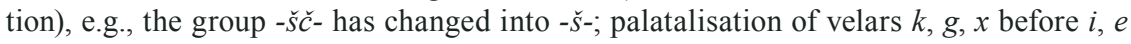
is still strong (npr. mú:še 'muhe', drù̀iga 'drugega').

This phonological description has been prepared on the basis of dialect recordings from 1967 (the material was collected with the questionnaire for Slovene Linguistic Atlas), complemented by recordings of dialect speech made in 2013. 